\section{A Rare Case of Scrotal Basal Cell Carcinoma in the Presence of Metastatic Squamous Cell Carcinoma of the External Auditory Meatus and its Management Strategy}

\author{
TAN GH ${ }^{1}$, ELSA JR ${ }^{1}$, FAM XI ${ }^{1}$, SHUKOR NA ${ }^{2}, \mathrm{GOH}^{2} \mathrm{H}^{1}$, PRAVEEN \\ $\mathrm{S}^{1}, \mathrm{HO} \mathrm{CCK}^{1}$, ZULKIFLI MZ1 \\ ${ }^{1}$ Urology Unit, Department of Surgery, ${ }^{2}$ Department of Pathology, Faculty of Medicine, \\ Universiti Kebangsaan Malaysia Medical Centre, Jalan Yaacob Latif, Bandar Tun Razak, \\ 56000 Cheras, Kuala Lumpur, Malaysia.
}

\begin{abstract}
ABSTRAK
Penyakit kanser sel basal (KSB) di bahagian skrotum jarang ditemui dan punca ia berlaku tidak difahami dengan baik. KSB yang tumbuh di skrotum ini dikatakan lebih agresif dan mempunyai kebolehan merebak yang lebih tinggi daripada KSB kawasan-kawasan lain. Rawatan utama untuk KSB peringkat awal di skrotum adalah pembedahan, manakala untuk peringkat lanjut di mana penyakit telah merebak, ia perlu dikawal dengan rawatan kemoterapi. Satu keadaan klinikal yang luar biasa di mana KSB skrotum berlaku serentak dengan kanser yang lain tidak pernah dilaporkan. Kes ini mengisahkan cabaran diagnostik dan rawatan kerana KSB skrotum dan kanser sel squamous (KSS) berlaku pada waktu yang sama. Seorang lelaki berusia 70 tahun mengadu wujudnya ulser di skrotum beliau yang tidak sembuh selama lebih setahun. Pada ketika itu, beliau sedang disiasat kerana mengalami penyakit KSS di telinga yang berada di peringkat lanjut. UIser di skrotum itu pada mulanya dianggap sebagai KSS yang telah merebak ke situ. la kemudiannya didapati penyakit KSB dengan biopsi dan pemeriksaan histopatologi. Beliau menjalani pembedahan untuk membuang ulser di skrotum dan diikuti dengan kemoterapi paliatif menggunakan cisplatin dan radioterapi ke atas kumpulankumpulan limpa yang dijangkiti KSS. Enam bulan selepas tamatnya rawatan paliatif, beliau kekal sihat dan tidak mempunyai apa-apa kesan KSB berulang di skrotum. Rawatan pembedahan bersama dengan kemoterapi dan radioterapi paliatif dapat memberi kualiti hidup yang baik untuk pesakit yang ditimpa KSB skrotum dan KSS peringkat lanjut.
\end{abstract}

Kata kunci: $\quad$ kanser sel basal, kanser cell squamous, skrotum

Address for correspondence and reprint requests: Tan Guan Hee, Urology Unit, Department of Surgery Faculty of Medicine, Universiti Kebangsaan Malaysia Medical Centre, Jalan Yaacob Latif, Bandar Tun Razak, 56000 Cheras, Kuala Lumpur, Malaysia. Tel: +60391456202 Fax: +60391456684 E-mail: drtan.guanhee@ gmail.com 


\section{ABSTRACT}

Basal cell carcinoma (BCC) of the scrotum is uncommon and its pathogenesis is not well understood. The clinical behaviour of scrotal BCC is thought to be more aggressive and has a higher metastatic potential than BCC of other regions. The mainstay of treatment for localized scrotal BCC is wide local excision, while metastatic disease may need systemic chemotherapy for palliative control. A rare clinical scenario of scrotal BCC presenting concurrently with another metastatic cancer has never been reported. The present case illustrates the diagnostic challenge and management dilemma due to simultaneous presentation of scrotal BCC and metastatic squamous cell carcinoma (SCC). A 70-year-old man complained of a non-healing scrotal ulcer while he was being investigated for metastatic squamous cell carcinoma (SCC) of the external auditory meatus. The scrotal lesion was initially thought to be metastatic SCC. It was later confirmed to be BCC with biopsy and histopathological examination. He underwent surgical resection of the scrotal BCC for local control followed by palliative chemotherapy with cisplatin and radiotherapy for lymph node metastases. He remained well and did not have any local recurrence following 6 months after palliative treatment. Surgery coupled with palliative chemoradiation can offer good quality of life for patients with scrotal BCC and concurrent metastatic SCC.

Keywords: basal cell carcinoma, squamous cell carcinoma, scrotum

\section{INTRODUCTION}

Basal cell carcinoma (BCC) is a skin malignancy that commonly affects sunexposed areas of the body such as the head and neck region (Jeon et al. 2006; Wang et al. 2010). However, BCC of the scrotum quite uncommon (Dai et al. 2012; Jeon et al. 2006; Kinoshita et al. 2005) and its pathogenesis is not well understood (Jeon et al. 2006). It is thought to be more aggressive and metastasizes earlier than BCC of other parts of the body (Kinoshita et al. 2005). Localized scrotal BCC is usually treated with wide local excision (Delto et al. 2016; Jeon et al. 2006; Ribuffo et al. 2002; Wang et al. 2010) but metastatic disease may require systemic chemotherapy for disease control
(Cieplinski 1984; Jeon et al. 2006). To our knowledge, scrotal BCC occurring concurrently with another metastatic carcinoma has never been reported. We encountered a rare case of scrotal BCC in the presence of metastatic squamous cell carcinoma (SCC) of the ear canal. This case illustrates the challenges encountered in diagnosing and treatment. It also highlights a palliative strategy that provides the patient with a good quality of life.

\section{CASE REPORT}

A 70-year-old male complained of having a chronic and non-healing ulcer on his left hemiscrotum for two yrs. He used to work as a supervisor at a chemical factory for over 20 
yrs. The job involved exposure and close contact with various chemicals including magnesium sulphate, nitric oxide, ammonia, paraquat, liquid hydrogen, chlorine gas and sulphur compounds. The scrotal lesion was made known to us while he was undergoing investigation for SCC of his right external auditory meatus. The SCC was found to have metastasized to the liver and lymph nodes in the abdomen and pelvis. The concomitant presence of this metastatic SCC raised the suspicion that the scrotal lesion could be a metastatic secondary. On physical examination, the lesion was located at the inferior part of the scrotum. It measured $3 \mathrm{~cm} \times 4 \mathrm{~cm}$ in size, and had pearly irregular borders and central ulceration (Figure 1). It had a hard consistency but it did not feel adherent to the underlying tunica vaginalis and testes. The clinical appearance of this scrotal lesion was uncharacteristic of SCC. His inguinal lymph nodes were also found to be enlarged bilaterally. A wedge biopsy of the scrotal lesion unexpectedly diagnosed it to be BCC instead of metastatic SCC (Figure 2).

He underwent wide local excision (WLE) of the scrotal lesion with the intention for local disease control. Intraoperatively, the tumour was resected with at least $1 \mathrm{~cm}$ macroscopic margin. However, the histopathological examination (HPE) showed nodular, infiltrative pattern BCC of the scrotum with inadequate resection margin. Meanwhile, he developed a new satellite scrotal sinus just near the base of penis. He subsequently underwent further excision of the scrotal scar and sinus. While the scrotal scar HPE

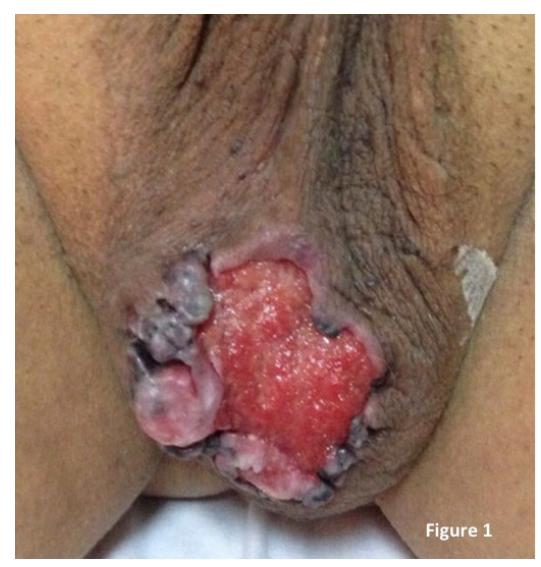

Figure 1: Scrotal lesion measuring $3 \mathrm{~cm} \times 4 \mathrm{~cm}$ over the inferior part of the scrotum. It had pearly irregular borders and a central ulceration.

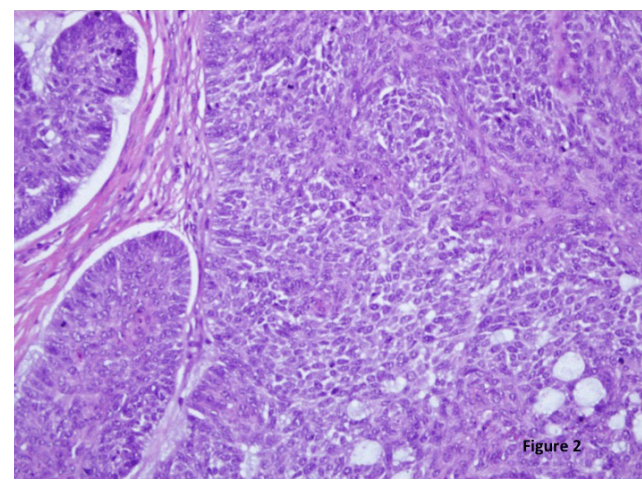

Figure 2: Histological features of basal cell carcinoma seen under microscopic examination (x200). It showed tissue made up of islands of closely packed malignant cells, palisaded outer row of cells and mucinous material surrounding the malignant cells. There were numerous mitotic figures and the stroma was infiltrated by lymphocytes and plasma cells.

showed good clearance margin this time, the scrotal sinus was found to harbour even more BCC. After surgery, he was treated with palliative chemoradiation consisting of 6 cycles of cisplatin $30 \mathrm{mg} / \mathrm{m}^{2}$, and 70 Gy in 35 fractions of radiotherapy to the metastatic neck and abdominal lymph nodes. He remained well six months 
after completing palliative treatment and there was no local recurrence of the scrotal BCC.

\section{DISCUSSION}

Basal cell carcinoma is the commonest skin cancer in most parts of the world (Lomas et al. 2012). It is widely accepted that excessive exposure to ultraviolet (UV) radiation is a major risk factor for developing BCC (Wang et al. 2010). Therefore, most BCC occur on parts of the skin that are usually exposed to sun (Jeon et al. 2006), and BCC of the scrotum is understandably quite uncommon (Dai et al. 2012; Jeon et al. 2006; Kinoshita et al. 2005). Unlike SCC of the scrotum that has several established risk factors, scrotal BCC does not have any clear relations with carcinogen exposure. (Jeon et al. 2006). Indeed, its pathogenesis still remains unclear and few postulations were proposed. These include impaired immune surveillance, genetic mutation and even chronic irritation (Jeon et al. 2006; Ouchi \& Sugiura 2008; Wang et al. 2010).

Scrotal BCC is also thought to behave more aggressively than its counterpart located elsewhere on the body. Metastatic scrotal BCC is known to occur much earlier, at around 2-3 yrs after the initial diagnosis; in contrast, BCC on other sites that metastasize at an average time of $11 \mathrm{yrs}$ after being diagnosed (Kinoshita et al. 2005). The commonest sites of metastasis are lymph nodes, lungs and bones (Kinoshita et al. 2005). Nevertheless, there was a single case report of scrotal BCC that remained dormant for over 50 yrs (Wang et al. 2010). Unfortunately, we were unable to predict which patient would have metastasis sooner than others. Previous attempts at using histological features to predict metastatic potential have been largely unsuccessful (Kinoshita et al. 2005). Therefore, we must remain vigilant for the possibility of early distant spread in all cases of scrotal BCC.

The present case was a diagnostic challenge to us because while the patient was being investigated for metastatic SCC of the external auditory meatus, he alerted us about an ulcerating lesion on his scrotum. The initial impression was that the scrotal lesion should also be squamous cell in origin and treatment would follow the course for SCC. However, a biopsy of the lesion found it to be BCC. This then posed a question of whether to wide local excision of the scrotal was appropriate in the presence of widespread metastatic SCC from his ear. Furthermore, we also faced a dilemma in deciding the systematic therapy that he should receive in this unusual situation.

Most authors agree that surgery is the mainstay of treatment for localized scrotal BCC (Delto et al. 2016; Jeon et al. 2006; Ribuffo et al. 2002; Wang et al. 2010). A clear surgical margin of $>6$ $\mathrm{mm}$ reduces the risk of disease relapse (Delto et al. 2016). Other authors advocate greater clear surgical margin of $2-3 \mathrm{~cm}$ for complete resection of the local disease (Hernández-Aragüés \& Baniandrés-Rodríguez 2016). In cases where metastases occurred, systemic chemotherapy should be administered (Cieplinski 1984; Jeon et al. 2006) and a cisplatin-based combination seems to 
produce acceptable results (Cieplinski 1984). Of particular note, metastatic scrotal SCC can also be treated with cisplatin in combination with methotrexate and bleomycin (Vyas et al. 2014).

We offered the patient wide local excision of his scrotal BCC as a means for local control and also to free him from the constant discomfort of an ulcerating lesion. This was followed by palliative systemic treatment with cisplatin chemotherapy, and radiotherapy to the metastatic lymph nodes at his neck and abdomen. This treatment strategy gave him a good quality of life at 6 months, post-chemoradiation.

\section{CONCLUSION}

In conclusion, a patient with scrotal BCC presenting concurrently with metastatic SCC of the ear is rare and can be a challenge to manage. A careful and individualized treatment plan, combining surgery, chemotherapy and radiotherapy can provide excellent palliative outcome in this clinical scenario.

\section{REFERENCES}

Cieplinski, W. 1984. Combination chemotherapy for the treatment of metastatic basal cell carcinoma of the scrotum. A case report. Clin Onco/ 10(3): 267-72.
Dai, B., Kong, Y.Y., Ye, D.W., Xu, X.W., Yao, X.D., Zhang, S.L. 2012. Basal cell carcinoma of the scrotum: clinicopathologic analysis of 10 cases. Dermatol Surg 38(5): 783-90.

Delto, J.C., Garces, S., Sidhu, A.S., Ghaffaripour, T., Omarzai, Y., Nieder, A.M. 2016. Giant Fungating Basal Cell Carcinoma of the Scrotum. Urology 91: e1-2.

Hernández-Aragüés, I., Baniandrés-Rodríguez, O. 2016. Basal cell carcinoma of the scrotum. Actas Urol Esp 40(9): 592-3.

Jeon, J., Song, H.J., Oh, C.H. 2006. Basal Cell Carcinoma of the scrotum. Ann Dermato/ 18(2): 97-9.

Kinoshita, R., Yamamoto, O., Yasuda, H., Tokura, Y. 2005. Basal cell carcinoma of the scrotum with lymph node metastasis: report of a case and review of the literature. Int J Dermatol 44(1): 54-6.

Lomas, A., Leonardi-Bee, J., Bath-Hextall, F. 2012. A systematic review of worldwide incidence of nonmelanoma skin cancer. $\mathrm{Br}$ J Dermatol 166(5): 1069-80.

Ouchi, T., Sugiura, M. 2008. Polypoid basal cell carcinoma on the scrotum. J Dermatol 35(12): 804-5.

Ribuffo, D., Alfano, C., Ferrazzoli, P.S., Scuderi, N. 2002. Basal cell carcinoma of the penis and scrotum with cutaneous metastases. Scand J Plast Reconstr Surg Hand Surg 36(3): 180-2.

Vyas, R., Zargar, H., Trolio, R.D., Di Lorenzo, G., Autorino, R. 2014. Squamous cell carcinoma of the scrotum: A look beyond the chimneystacks. World J Clin Cases 2(11): 654-60.

Wang, J.W., Man, L.B., He, F., Huang, G.L., Li, G.Z., Wang, H.D. 2010. Images for diagnosis . Basal cell carcinoma of the scrotum: report of a case and review of the literature. Chin Med J (Engl) 123(19): 2748-9.

Received: 27 October 2016

Accepted: 20 February 2017 